\title{
Edukasi dan Aplikasi Pengelolaan Sampah Berbasis Pemilahan Sampah di Lingkungan Fakultas Farmasi Universitas Pancasila
}

\author{
Nurita Andayani' ${ }^{1}$, Esti Mulatsari², Moordiani ${ }^{3}$, Sondang Khairani4, \\ Gressty F Swandiny ${ }^{5}$
}

\begin{abstract}
1Program Studi Magister Ilmu Kefarmasian, Fakultas Farmasi Universitas Pancasila, Indonesia email: nurita.andayani@univpancasila.ac.id

2,4Program Studi Sarjana Farmasi, Fakultas Farmasi Universitas Pancasila, Indonesia email: 2esti.mulatsari@univpancasila.ac.id, ${ }^{4}$ sondang.khairani@univpancasila.ac.id

3Program Studi Diploma 3 Farmasi, Fakultas Farmasi Universitas Pancasila, Indonesia

email: mdiani@univpancasila.ac.id

5Program Studi Doktor Ilmu Farmasi, Fakultas Farmasi Universitas Pancasila, Indonesia

email: greestyfinotory@gmail.com
\end{abstract}

\begin{abstract}
Abstrak
Fakultas Farmasi Universitas Pancasila (FFUP) merupakan salah satu fakultas yang ada di Universitas Pancasila yang memiliki jumlah mahasiswa cukup banyak. Selain itu, di Fakultas Farmasi Universitas Pancasila terdapat 9 kios kantin yang sehariharinya melayani kebutuhan makanan dan minuman dari sivitas akademika FFUP serta fakultas lain di Universitas Pancasila yang berdampingan langsung dengan Fakultas Farmasi. Kondisi ini berpotensi menimbulkan suatu masalah yaitu penumpukan sampah. Secara umum kesadaran sivitas akademika dan orang-orang yang beraktivitas di lingkungan FFUP mengenai sampah masih kurang. Oleh karena itu, edukasi, sosialisasi dan aplikasi mengenai pemilahan sampah sangat diperlukan di lingkungan FFUP yang berguna dalam mengurangi frekuensi sampah. Edukasi dan aplikasi telah dilakukan melalui kegiatan penyuluhan, pengadaan fasilitas pemilahan sampah, dan pelatihan aplikasi pemanfaatan sampah kepada seluruh sivitas akademika FFUP yang dilaksanakan secara daring dan luring (September Desember 2020). Program ini cukup berhasil meningkatkan pengetahuan civitas akademika tentang pengelolaan sampah berbasis pemilahan sampah dengan kenaikan pemahaman dan kepedulian tentang pengelolaan sampah sebesar 4,58\%, dan $8,94 \%$ secara berturut - turut dan telah diterapkan nya sistem pemilahan sampah di FFUP
\end{abstract}

Kata Kunci: FFUP, Sampah, Edukasi, Aplikasi

\section{Abstract}

The Faculty of Pharmacy, Universitas Pancasila (FFUP) is one of the faculties at Universitas Pancasila which has a large number of students. In addition, at the FFUP there are 9 canteen 
that serve the daily food and beverage needs of the FFUP academic community and other faculties at Universitas Pancasila which are directly adjacent to the Faculty of Pharmacy. This condition has the potential to cause a problem, i.e the accumulation of waste. In general, the awareness of the academic community and people who are active in the FFUP environment regarding waste is still lacking. Therefore, education, socialization and applications regarding waste sorting are very much needed in the FFUP community which is useful in reducing the frequency of waste. Education and applications have been carried out through extension activities, procurement of waste sorting facilities, and training on waste utilization applications to all FFUP academic community which were carried out online and offline (September - December 2020). This program is quite successful in increasing the knowledge of the academic community about waste management based on waste sorting with an increase in understanding and concern about waste management by $4.58 \%$, and $8.94 \%$, respectively, and the implementation of the waste sorting system in FFUP.

Keywords: FFUP, Waste, Education, Application

\section{Pendahuluan}

Pengelolaan sampah menjadi perhatian penting oleh pemerintah yang dituangkan dalam Undang-Undang Republik Indonesia Nomor 18 Tahun 2008 tentang Pengelolaan Sampah dimana sampah adalah sisa kegiatan sehari-hari manusia dan atau proses alam yang berbentuk padat. Pada tahun 2020, pemerintah mengeluarkan kembali peraturan terkait dengan pengelolaan sampah yang lebih spesifik yang tertuang dalam Peraturan Pemerintah Republik Indonesia Nomor 27 Tahun 2020 tentang pengelolaan sampah spesifik. Sampah spesifik yang dimaksud adalah sampah yang karena sifat, konsentrasi, dan volumenya memerlukan perlakuan khusus seperti sampah masker yang termasuk dalam sampah medis B3. Di Fakultas Farmasi Universitas Pancasila (FFUP) merupakan salah satu fakultas yang ada di Universitas Pancasila yang memiliki jumlah mahasiswa cukup banyak. Saat ini mahasiswa yang tercatat aktif di semester genap 2017/2018 sebanyak 1566 mahasiswa dan 187 karyawan dan dosen. Selain itu, di Fakultas Farmasi Universitas Pancasila terdapat 9 kios kantin yang sehari-harinya melayani kebutuhan makanan dan minuman dari sivitas akademika serta fakultas lain di Universitas Pancasila yang berdampingan langsung dengan Fakultas Farmasi. Kondisi inilah yang berpotensi menimbulkan masalah baru yaitu sampah. Tanpa disadari kegiatan sehari-hari akan banyak menghasilkan sampah baik sampah basah dan kering maupun sampah organik dan anorganik. Selama ini sampah hanya dikumpulkan kemudian dibuang pada pembuangan akhir Universitas Pancasila. Sampah-sampah organik yang berasal dari tanaman misalnya daun-daun dan batang tanaman dikumpulkan kemudian dibakar untuk dijadikan pupuk, sedangkan sampah hasil dari kegiatan sehari-hari masih dibuang tanpa adanya pemilahan. Pengolahan sampah organik menjadi pupuk dengan cara dibakar tentunya bukan solusi yang baik, karena akan menimbulkan polusi udara dan bau di lingkungan FFUP. Sedangkan penumpukan sampah hasil kegiatan sehari-hari di pembuangan akhir akan berdampak pada pandangan yang tak sedap dan bau yang tidak enak. Sampah yang dihasilkan oleh FFUP rata-rata 2 meter kubik setiap hari yang terdiri dari 
sampah kemasan makanan dan minuman serta kertas atau dokumen yang sudah tidak terpakai.

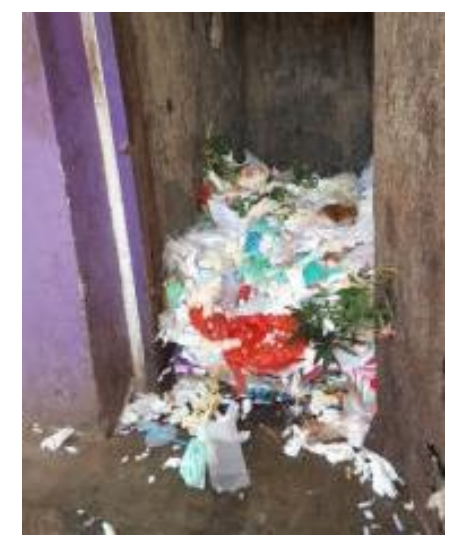

Gambar 1. Pembuangan sampah akhir FFUP

Secara umum kesadaran sivitas akademika dan orang-orang yang beraktivitas di lingkungan FFUP mengenai sampah masih kurang. Menurut penelitian Suharjo (2002), pengelolaan sampah yang tidak baik akan berdampak pada gangguan kesehatan pada masyarakat seperti timbulnya berbagai penyakit dan pencemaran air tanah dan polusi udara, serta salah satu penyebab banjir. Namun demikian sampah juga tidak hanya dipandang sudut negatif saja, sampah juga memiliki nilai ekonomis jika dikelola dengan baik sebagaimana telah dilakukan oleh Handayani dll (2009). Pengelolaan sampah yang baik juga sebagai bagian dari implementasi Sustainable Development Goals (SDGs) dalam menjaga lingkungan. (Hardiana, 2018).

Penyelesaian masalah sampah tidak dapat dilakukan dengan hanya mengandalkan petugas kebersihan. Seluruh sivitas akademika dan orang-orang yang beraktivitas di lingkungan FFUP harus turut serta membantu pemerintah dalam menangani masalah sampah. Menjaga lingkungan merupakan tanggup jawab bersama yang dimulai sejak dini yaitu dari lingkungan sekolah atau Pendidikan. (BPS, 2017). Menurut penelitian Sukib, Muti'ah, Siahaan, J., Supriadi. (2019), edukasi mengenai pengelolaan sampah laut dapat meningkatkan pengetahuan dan kesadaran masyarakat Pantai Kuranji dalam bahaya sampah laut. Oleh karena itu peneliti ingin melakukan edukasi dan sosialisasi mengenai pengelolaan sampah berbasis pemilahan sampah sangat diperlukan di lingkungan FFUP yang berguna untuk meningkatkan kesadaran sivitas akademika FFUP dalam mengurangi frekuensi sampah dengan memanfaatkan sampah. Oleh karena itu edukasi dan sosialisasi mengenai pengelolaan sampah berbasis pemilahan sampah sangat diperlukan di lingkungan FFUP yang berguna dalam mengurangi frekuensi sampah dengan memanfaatkan sampah.

\section{Metode}

Metode pelaksanaan kegiatan pengabdian ini disesuaikan dengan analisis kondisi yang telah dilakukan oleh tim pelaksana, dimana analisis kondisi disampaikan dalam Tabel 1. 
Tabel 1. Analisis Permasalahan Mitra dan Solusi

\begin{tabular}{|l|l|}
\hline \multicolumn{1}{|c|}{ Permasalahan Mitra } & \multicolumn{1}{c|}{ Solusi } \\
\hline $\begin{array}{l}\text { Masih Kurangnya kesadaran sivitas akademika } \\
\text { terutama mahasiswa, pedagang dan petugas } \\
\text { kebersihan di lingkungan FFUP }\end{array}$ & $\begin{array}{l}\text { Melakukan edukasi terkaiy pengelolaan } \\
\text { sampah berbasis pemilahan sampah }\end{array}$ \\
\hline $\begin{array}{l}\text { Belum ada fasilitas pemilahan sampah dan } \\
\text { pengelolaan sampah yang memadai di } \\
\text { lingkungan FFUP }\end{array}$ & $\begin{array}{l}\text { Membuat system pembuangan sampah } \\
\text { berbasis pemilahan sampah di lingkungan } \\
\text { FFUP dengan cara menyediakan tempat } \\
\text { sampah dengan pemilah antara sampah } \\
\text { organik, anorganik, dan sampah medis (B3) }\end{array}$ \\
\hline $\begin{array}{l}\text { Belum adanya komunitas yang bergerak dalam } \\
\text { pengelolaan sampah }\end{array}$ & $\begin{array}{l}\text { Pelatihan pembuatan biopori untuk mengelola } \\
\text { sampah kering dan pembuatan ecoenzyme } \\
\text { untuk mengelola sampah organik }\end{array}$ \\
\hline
\end{tabular}

Dalam mencapai solusi atas permasalahan mitra tersebut tim melakukan kegiatan pengabdian kepada masyarakat dengan tahapan sebagai berikut :

Tahap Persiapan. Dalam pelaksanaan PkM perlu melakukan persiapan agar kegiatan dapat berlangsung dengan baik dan memiliki manfaat terutama bagi mitra. Persiapan yang tim PkM lakukan adalah a) melakukan koordinasi dengan pihak Fakultas. Koordinasi dilakukan untuk mengurus perijinan kegiatan dan peminjaman tempat, b) menyiapkan materi tentang pemilahan sampah, pembuatan ecoenzyme, dan pengelolaan sampah masker medis sekali pakai. Materi presentasi dibuat dalam bentuk slide power point dan poster yang bisa dipasang di berbagai sudut ruang. Selain materi tim PkM juga membuat tes untuk mengetahui pengetahuan peserta terkait sampah dan pemilahan sampah yang diberikan sebelum penyuluhan (prestest) dan tes setelah penyuluhan (pos-test) untuk evaluasi kegiatan, c) menjalin kerjasama dengan narasumber (praktisi lingkungan) untuk memberi materi pemanfaatan sampah organik sebagai bahan pembuatan ecoenzyme.

Tahap Pelaksanaan. Tahap awal pelaksaan kegiatan dilakukan proses edukasi dan penyuluhan dengan memberi penyuluhan kepada seluruh sivitas akademika FFUP dengan judul "Edukasi dan Aplikasi Pengelolaan Sampah Berbasis Pemilahan Sampah". Penyuluhan dilakukan oleh tim Penyuluh yang terdiri atas Nurita Andayani, Esti Mulatsari, Moordiani, Sondang Khairani, dan Greesty F. Swandiny dengan melibatkan praktisi lingkungan tentang ecoenzyme oleh Fenti Atmawinata. Kegiatan penyuluhan dilakukan secara luring dan daring mengingat kondisi pandemik. Penyuluhan tahap pertama edukasi diberikan secara luring kepada dosen, tenaga kependidikan, penjual kantin, dan petugas kebersihan (Cleaning Service) dilingkungan FFUP. Pada tahap kedua edukasi diberikan secara daring kepada mahasiswa, dosen, dan tenaga kependidikan FFUP. Tahap selanjutnya adalah aplikasi dari kegiatan edukasi yaitu penerapan sistem pembuangan sampah berbasis pemilahan sampah dengan menyediakan tempat sampah dengan pemisah antara sampah organik, anorganik, dan sampah medis (B3) dan membuat poster edukasi di beberapa sudut ruangan FFUP.

Tahap Evaluasi. Tahap evaluasi kegiatan dilakukan dengan proses mengolah data dari kuesioner yang diberikan baik pre-test maupun post-test. Kuesioner berguna 
untuk mengetahui perubahan pemahaman dan sikap peserta terkait pengelolaan sampah berbasis pemilahan, yang secara garis besar memuat pertanyaan pertanyaan mencakup pemahaman, sikap dan perilaku sivitas akademik terkait sampah, pemilahan sampah, dan pemanfaatan sampah (Saputra dan Mulasari, 2017). Pengolahan data menggunakan uji t-berpasangan (paired t-test) untuk mengetahui perubahan pemahaman dan sikap peserta (Walpole, 1995). Jika nilai Sig $\leq 5 \%$ maka uji menyimpulkan bahwa terdapat perbedaan ukuran sebelum dan sesudah penyuluhan, sedangkan jika nilai Sig > 5\% maka uji menyimpulkan tidak terdapat perbedaan ukuran sebelum dan sesudah penyuluhan.

\section{Hasil dan Pembahasan}

Tahap Persiapan. Pada tahap persiapan seluruh tim melakukan kordinasi persiapan kegiatan agar pelaksanaan dapat berlangsung dengan baik dan memberi manfaat maksimal terutama bagi mitra. Pada tahap persiapan koordinasi dengan mitra (FFUP) dilakukan untuk mengurus perijinan kegiatan dan peminjaman tempat, dimana acara edukasi dan sosialisasi akan dilakukan secara daring dan luring sehingga perlu disiapkan tempat untuk acara luring dan link zoom meeting untuk kegiatan daring. Tim PkM bekerja sama dengan petugas fakultas untuk menyediakan sarana dan prasarana untuk teknis edukasi dan sosialisasi. Persiapan materi dilakukan dengan membuat slide presentasi dengan beberapa pokok bahasan antara lain :

a. Pemilahan dan Pengolaan Sampah (pengetahuan tentang jenis-jenis sampah, sifat-sifat sampah, dan teknik pengelolaan sampah)

b. Pemanfaatan Sampah Organik menjadi Ecoenzym

c. Pengelolaan Sampah Masker

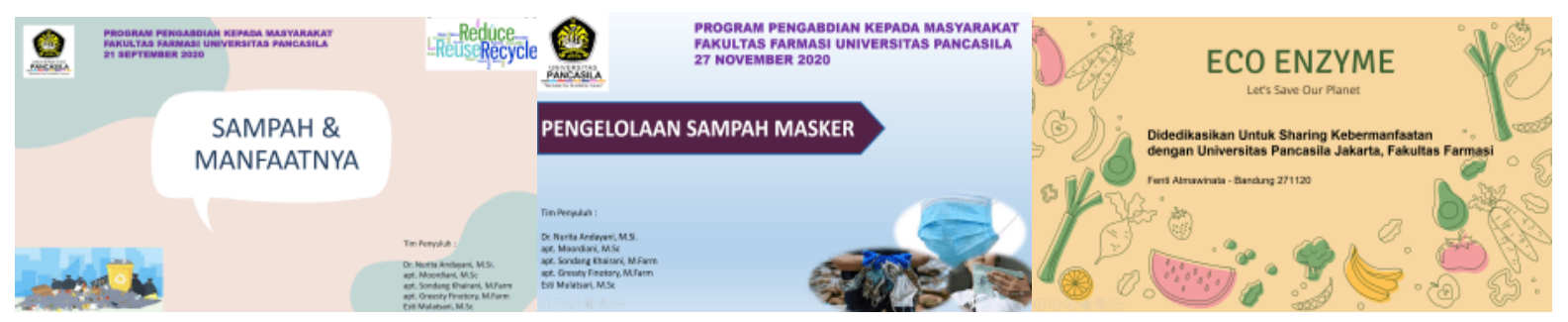

Gambar 2. Materi Edukasi dan Sosialisasi

Selain mempersiapkan sarana dan prasaran serta materi tim juga melakukan persiapan materi pretest dan post test yang dapat diakses dengan gform ataupun secara langsung mengisi kuisioner. Tim PKM juga melakukan persiapan dengan melakukan koordinasi dengan narasumber yang ahli dalam bidang pengolahan sampah, yaitu Ibu Fenti Atmawinata, S.St. yang merupakan praktisi di bidang lingkungan dan pakar dalam pembuatan ecoenzyme serta aplikasinya untuk kebutuhan sehari - hari. Eco Enzyme adalah memiliki kandungan Asam Asetat $(\mathrm{H} 3 \mathrm{COOH})$, yang dapat membunuh kuman, virus dan bakteri. Sedangkan kandungan Enzyme itu sendiri adalah Lipase, Tripsin, Amilase dan Mampu membunuh / mencegah bakteri Patogen. Selain itu juga dihasilkan NO3 (Nitrat) dan 
CO3 (Karbon trioksida) yang dibutuhkan oleh tanah sebagai nutrient. Dari segi ekonomi, pembuatan enzim dapat mengurangi konsumsi untuk membeli cairan pembersih lantai ataupun pembasmi serangga (Eviati \& Sulaeman. 2009). Hal ini dapat memberi inspirasi bagi peserta pelatihan baik untuk pemenuhan kebutuhan sehari-hari ataupun membuat produk komersial dari ecoenzyme.

Tahap Pelaksanaan. Tahap pelaksanaan kegiatan PKM diawali dengan kegiatan edukasi dalam bentuk penyuluhan kepada seluruh civitas akademika FFUP dengan Teknik luring dan daring. Teknik luring dilakukan dengan sasaran peserta pedagang kantin dan petuga kebersihan FFUP yang nota bene belum berpengalaman dalam penggunaan media daring, proses penyuluhan dilakukan dengan penerapan prokes. Kegiatan penyuluhan luring ini dilakukan pada tanggal 21 September 2020 yang dihadiri 50 peserta. Pada acara tersebut disampaikan materi tentang jenis-jenis sampah, sifat-sifat sampah, dan teknik pengelolaan sampah. Pemilihan materi ini bertujuan agar pedagang kantin memahami bagaimana cara memilah sampah yang dihasilkan setelah proses memasak dan bagi petugas kebersihan FFUP dapat memahami jenis - jenis sampah di lingkungan FFUP dan bagaimana memilahnya. Pelaksanaan secara daring (webinar) dilakukan pada tanggal 27 November 2020 dengan sasaran peserta adalah mahasiswa, dosen dan masyarakat umum. Kegiatan webinar tersebut dihadiri 178 Peserta. Dalam webinar tersebut disampaikan materi tentang Pemilahan dan Pengolaan Sampah dan Pengelolaan Sampah Masker yang disampaikan oleh tim pkm sebagai narasumber dan materi tentang Pemanfaatan Sampah Organik menjadi Ecoenzym yang disampaikan oleh praktisi lingkungan Ibu Fenti Atmawinata, S.St.

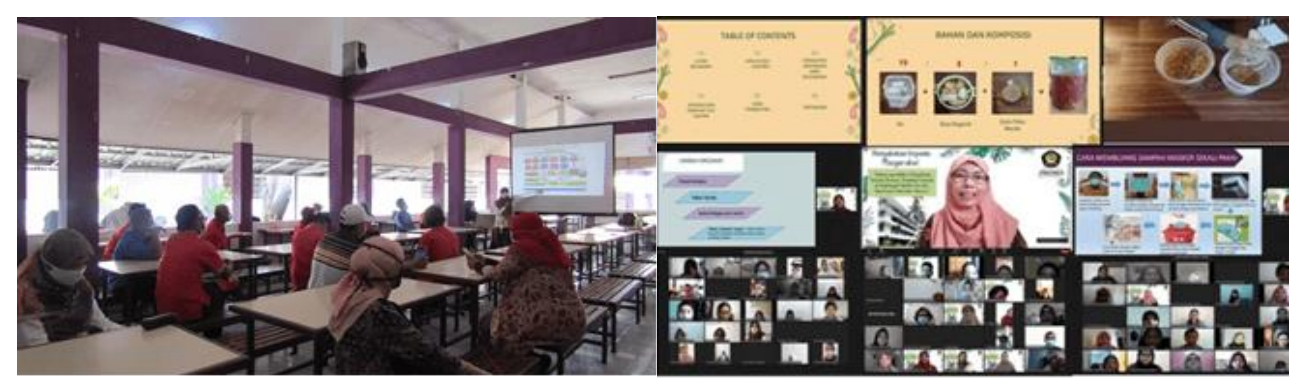

Gambar 3. Suasana kegiatan edukasi / penyuluhan Secara Luring dan Daring

Kegiatan penyuluhan baik daring maupun luring diikuti oleh peserta dengan sangat antusias. Tidak sedikit yang bertanya untuk memperdalam wawasan mereka. Dalam pelaksanaan penyuluhan diawal dan diakhir acara seluruh peserta diminta untuk mengisi formulif pretest dan posttest untuk mengukur keberhasilan program edukasi. Setelah proses edukasi melalui penyuluhan tim juga melakukan pemasangan poster di beberapa tempat strategis FFUP untuk memberi suasana edukasi setiap hari.

Setelah kegiatan penyuluhan / edukasi, selanjutnya tim PKM melakukan proses implemetntasi terhadap materi edukasi yang telah dilakukan. Beberapa kegiatan yang telah dilakukan antara lain bekerja sama dengan pihak fakultas melakukan 
pemasangan tempat sampah dengan pemilahan berdasarkan jenis sampah yaitu sampah organic, anorganik, dan medis (B3) di berbagai sudut ruang FFUP. Pengadaan ini bertujuan untuk memfasilitasi proses pemilahan sampah di lingkungan FFUP.

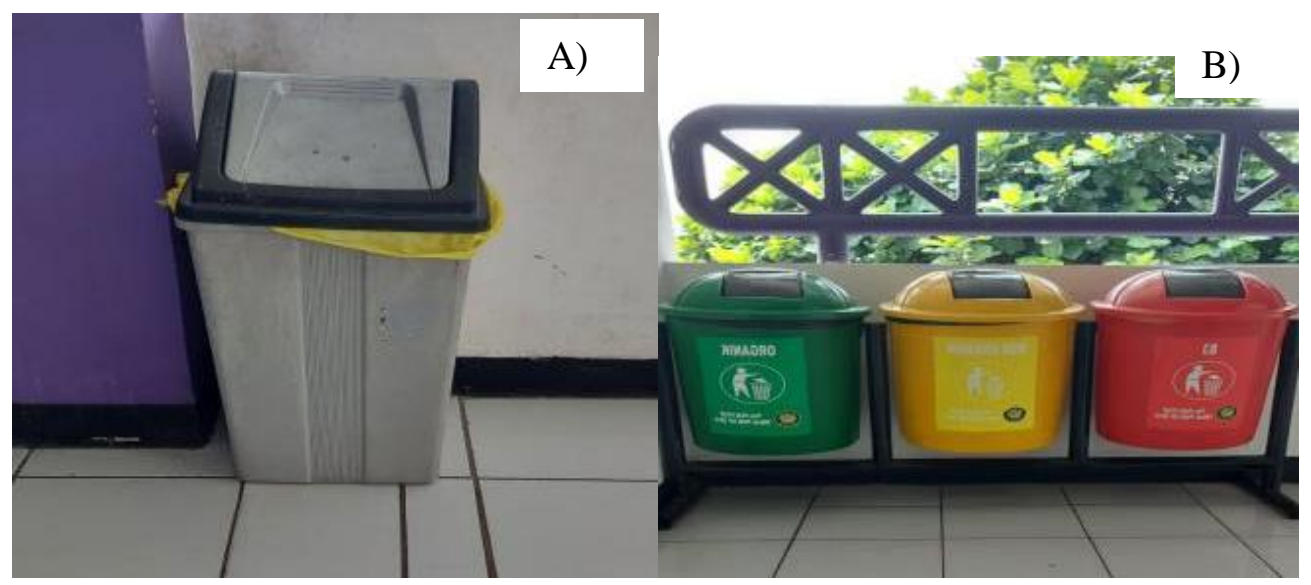

Gambar 4. Tempat sampah di FFUP A) Sebelum Kegiatan PKM B) Sesudah adanya kegiatan PKM

Selain itu, tim PKM juga melakukan pelatihan pembuatan biopori di lingkungan FFUP untuk para petugas kebersihan FFUP. Pembuatan biopori ini bertujuan untuk memelihara lingkungan dan aplikasi pemnfaatan sampah organic kering di lingkungan FFUP. Biopori mampu meningkat kan daya penyerapan tanah terhadap air sehingga risiko terjadinya penggenangan air (waterlogging) semakin kecil. Air yang tersimpan ini dapat menjaga kelembaban tanah bahkan di musim kemarau. Keunggulan ini dipercaya bermanfaat sebagai pencegah banjir. Dinding lubang biopori akan membentuk lubanglubang kecil (pori-pori) yang mampu menyerap air. Sehingga dengan lubang berdiameter $10 \mathrm{~cm}$ dan kedalaman $100 \mathrm{~cm}$, dengan perhitungan geometri tabung sederhana akan didapatkan bahwa lubang akan memiliki luas bidang penyerapan sebesar $3.220,13 \mathrm{~cm}^{2}$. Tanpa biopori, area tanah berdiameter $10 \mathrm{~cm}$ hanya memiliki luas bidang penyerapan $78 \mathrm{~cm}$ persegi (Kamir \& Nelistya, 2008) .
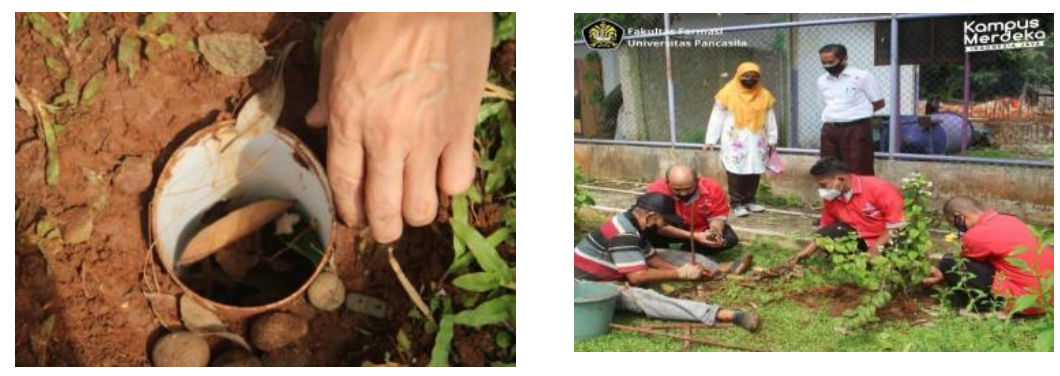

Gambar 5. Pelatihan Pembuatan dan Perawatan Biopori di lingkungan FFUP

Tahap Evaluasi. Pelaksanaan edukasi berupa penyuluhan diukur dari 3 aspek yaitu pemahaman, sikap, dan perilaku peserta terkait pengelolaan dan pemilahan sampah baik sebelum penyuluhan dan setelah penyuluhan. Pengukuran dilakukan dengan pengisian kuesioner dengan Google Form. Pengukuran pemahaman menggunakan skala likert yang mana setiap pernyataan berisi 4 skala yaitu 1 (sangat tidak setuju), 2 
(tidak setuju), 3 (setuju), dan 4 (sangat tidak setuju). Pernyataan dibuat dengan penyataan yang benar sehingga jika peserta menjawab jawaban 3 dan 4 maka dikategorikan paham. Hasil pengukuran pemahaman peserta sebelum dan setelah penyuluhan disajikan pada Tabel 2.

Tabel 2. Pemahaman peserta penyuluhan terhadap pengelolaan sampah

\begin{tabular}{|c|l|c|c|}
\hline Kode & Pernyataan & Sebelum (\%) & Sesudah (\%) \\
\hline A1 & Pengertian sampah & 57,1 & 73,4 \\
\hline A2 & Jenis-jenis sampah & 81,6 & 85,0 \\
\hline A3 & Pengertian sampah anorganik & 89,8 & 92,5 \\
\hline A4 & Pengertian sampah organik & 84,2 & 84,4 \\
\hline A5 & Contoh-contoh sampah organik & 88,4 & 90,8 \\
\hline A6 & Contoh-contoh sampah anorganik & 95,4 & 96,5 \\
\hline A7 & Dampak jika sampah tidak dikelola dengan baik & 99,5 & 100,0 \\
\hline A8 & Kategori sampah Masker medis & 19,4 & 32,9 \\
\hline A9 & Pemanfaatan limbah organik & 96,4 & 98,3 \\
\hline A10 & Sampah juga memiliki nilai manfaat meskipun & 90,3 & 97,1 \\
\hline b11 & Penyak mempunyai dampak negatif & & \\
\hline A12 & Pengertian Reuse & 78,6 & 85,5 \\
\hline A13 & Pengertian Recycle & 93,4 & 97,7 \\
\hline A14 & Pengertian Reduce & 99,0 & 98,3 \\
\hline A15 & Dampak pengelolaan sampah yang tidak baik & 92,3 & 98,3 \\
\hline & Rata-rata & 95,9 & 99,4 \\
\hline
\end{tabular}

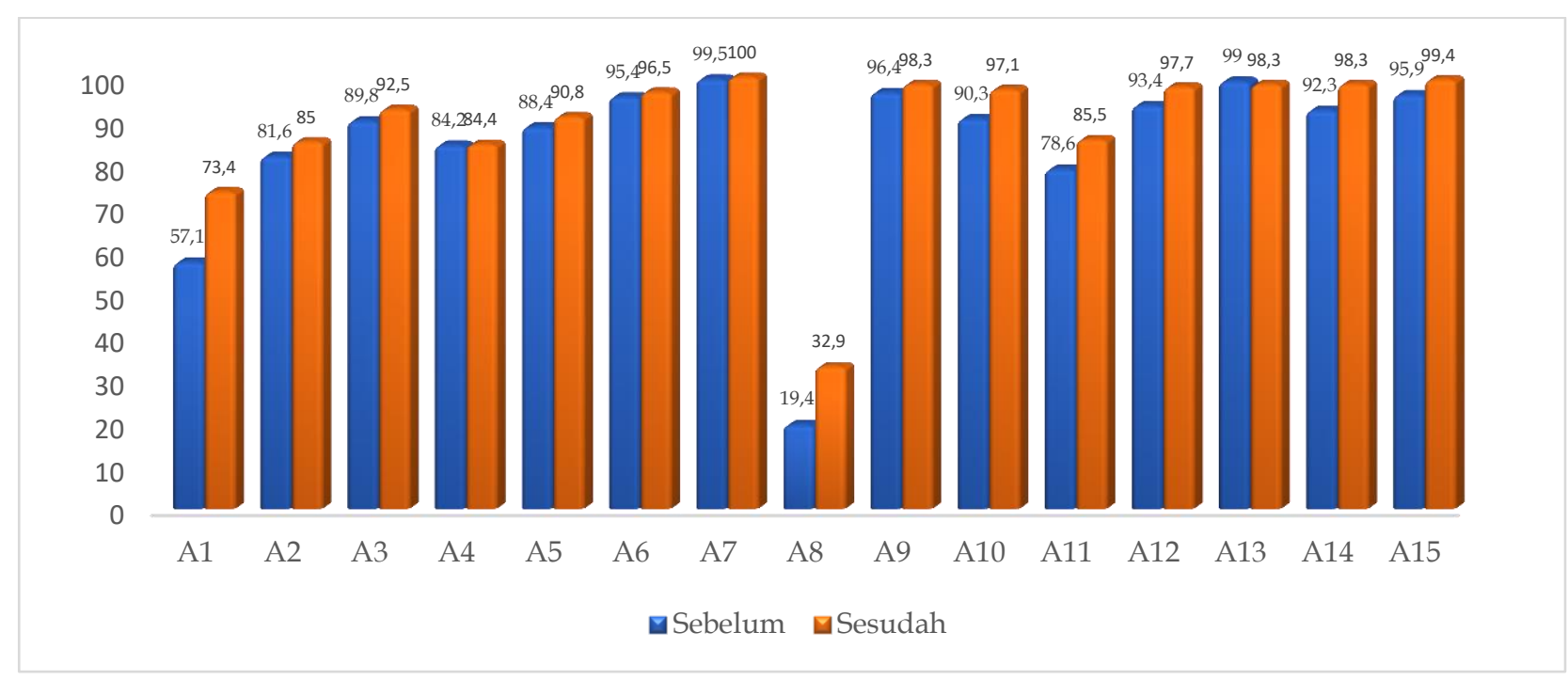

Gambar 6. Grafik pemahaman peserta penyuluhan terhadap pengelolaan sampah

Gambar 6 menunjukkan pemahaman peserta meningkat sebesar 4,58\% setelah penyuluhan, dimana pemahaman peserta sebelum penyuluhan $84,09 \%$ dan setelah penyuluhan $88,67 \%$. Secara umum peserta dapat dikategorikan sudah cukup paham terkait pengelolaan dan pemilahan sampah namun setelah penyuluhan pemahaman menjadi meningkat. Hasil uji statistik peningkatan pemahaman tentang pengelolaan 
sampah disajikan pada Tabel 2 dengan menggunakan uji t-berpasangan dengan taraf nyata 0,05 . Uji menggunakan hipotesis $\mathrm{H} 0$ menyatakan tidak terdapat perbedaan pemahaman terhadap pengelolaan sampah dan $\mathrm{H} 1$ menyatakan terdapat perbedaan pemahaman terhadap pengelolaan sampah.

Tabel 3. Uji t-berpasangan pemahaman pengelolaan sampah

\begin{tabular}{|c|c|c|c|}
\hline \multicolumn{2}{|c|}{ Pemahaman (rata-rata \%) } & Uji t-berpasangan & Kesimpulan \\
\hline Sebelum penyuluhan & $\begin{array}{c}\text { Setelah } \\
\text { penyuluhan }\end{array}$ & Menolak H0 \\
\hline 84,09 & 88,67 & 0,006 & Me6 \\
\hline
\end{tabular}

Hasil uji menunjukkan nilai Sig $=0,006(\leq 5 \%)$ sehingga uji menolak H0 yang berarti terdapat perbedaan pemahaman terkait pengelolaan sampah sebelum dan sesudah penyuluhan. Berdasarkan nilai rata-rata sikap benar menunjukkan bahwa, nilai ratarata pemahaman setelah penyuluhan $(88,67 \%)$ lebih besar dibandingkan sebelum penyuluhan $(84,09 \%)$. Hal ini menunjukkan bahwa penyuluhan efektif telah meningkatkan pemahaman dalam pengelolaan sampah peserta penyuluhan.

Pengukuran berikutnya untuk melihat perubahan sikap peserta tentang pengelolaan sampah yang disajikan pada Tabel 3 dan Gambar 8. Pengukuran sikap yang benar peserta tentang pengelolaan sampah menggunakan jawaban Benar dan Salah untuk setiap pernyataan. Terdapat 15 pernyataan yang terbagi terbagi menjadi 3 (tiga) kelompok pernyataan yaitu Memilah Sampah (7 pernyataan), Mengurangi Sampah (5 pernyataan), dan Memanfaatkan Sampah (3 pernyataan).

Tabel 4. Sikap yang benar peserta penyuluhan tentang pengelolaan sampah

\begin{tabular}{|l|c|c|}
\hline \multirow{2}{*}{\multicolumn{1}{|c|}{ Pernyataan }} & \multicolumn{2}{c|}{ Sikap yang benar tentang Pengelolaan Sampah (\%) } \\
\cline { 2 - 3 } & Rata-rata Sebelum & Rata-rata Sesudah \\
\hline Memilah Sampah $(\mathrm{N}=7)$ & 95,37 & 96,97 \\
\hline Mengurangi Sampah $(\mathrm{N}=5)$ & 94,74 & 96,10 \\
\hline Memanfaatkan Sampah $(\mathrm{N}=3)$ & 86,07 & 86,5 \\
\hline
\end{tabular}

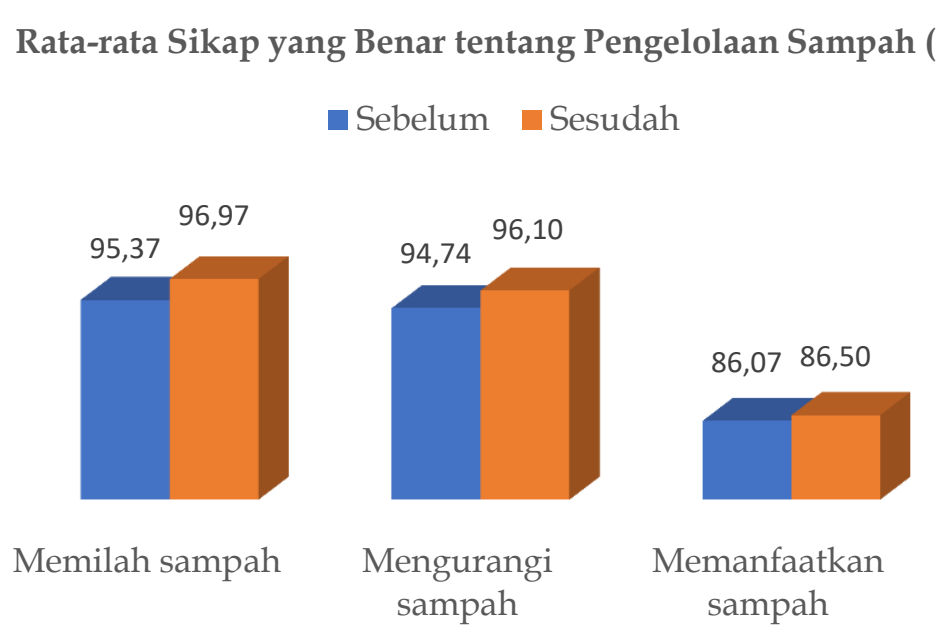

Gambar 7. Grafik sikap yang benar peserta penyuluhan terhadap pengelolaan sampah 
Pengujian statistik untuk melihat keefektifan penyuluhan dalam meningkatkan sikap benar peserta tentang pengelolaan sampah menggunakan uji t-berpasangan untuk 15 pernyataan. Hipotesis yang digunakan adalah $\mathrm{H} 0$ menyatakan tidak terdapat perbedaan sikap benar terhadap pengelolaan sampah dan H1 menyatakan terdapat perbedaan sikap benar terhadap pengelolaan sampah.

Tabel 5. Uji t-berpasangan sikap benar pengelolaan sampah

\begin{tabular}{|c|c|c|c|}
\hline \multicolumn{2}{|c|}{ Sikap benar (rata-rata \%) } & \multirow{2}{*}{$\begin{array}{c}\text { Uji t- } \\
\text { berpasangan } \\
\text { (Sig) }\end{array}$} & Kesimpulan \\
\cline { 1 - 2 } $\begin{array}{c}\text { Sebelum penyuluhan } \\
\mathbf{( N = 1 5 )}\end{array}$ & $\begin{array}{c}\text { Sesudah penyuluhan } \\
(\mathrm{N}=15)\end{array}$ & 0,019 & Menolak H0 \\
\hline $\mathbf{9 3 , 4 7}$ & 94,41 & \\
\hline
\end{tabular}

Hasil uji menunjukkan nilai Sig = 0,019 ( $\leq 5 \%)$ sehingga uji menolak H0 yang berarti terdapat perbedaan sikap benar terkait pengelolaan sampah sebelum dan sesudah penyuluhan. Berdasarkan nilai rata-rata sikap benar menunjukkan bahwa, nilai ratarata sikap benar setelah penyuluhan $(94,41 \%)$ lebih besar dibandingkan sebelum penyuluhan $(93,47 \%)$. Hal ini menunjukkan bahwa penyuluhan efektif telah meningkatkan sikap benar dalam pengelolaan sampah peserta penyuluhan sebesar $0,94 \%$.

Perubahan sikap benar dalam pengelolaan sampah diharapkan akan meningkatkan sikap peduli terhadap pengelolaan sampah. Jika masyarakat peduli terhadap sampah dan pengelolaan sampah maka penumpukan sampah dapat dikurangi karena sampah dapat dimanfaatkan kembali. Pengukuran perilaku peduli pengelolaan sampah menggunakan 10 pernyataan dengan 3 (tiga) pilihan jawaban yaitu Benar, Salah, dan Tidak Yakin. Peserta yang menjawab "Benar" dalam pernyataan memiliki arti bahwa peserta menyetujui pernyataan yang diberikan, jawaban "Salah" dalam pernyataan memiliki arti bahwa peserta tidak menyetujui pernyataan, dan jawaban "Tidak Yakin" memiliki arti peserta belum yakin akan jawabannya. Hasil dari pengukuran perilaku peserta penyuluhan terhadap pengelolaan sampah disajikan dalam Tabel 6 dan Gambar 8.

Tabel 6. Perilaku peserta penyuluhan terhadap pengelolaan sampah

\begin{tabular}{|l|l|c|c|}
\hline \multirow{2}{*}{ Kode } & \multicolumn{1}{|c|}{ Pernyatan } & \multicolumn{2}{c|}{$\begin{array}{c}\text { Perilaku peduli pengelolaan } \\
\text { sampah (\%) }\end{array}$} \\
\cline { 3 - 4 } & \multicolumn{1}{|c|}{ Sebelum } & Sesudah \\
\hline C1 & Tempat saya melakukan aktifitas tersedia tempat sampah & 92,49 & 95,92 \\
\hline C2 & $\begin{array}{l}\text { Tempat sampah yang tersedia di tempat saya melakukan } \\
\text { aktifitas memiliki penutup }\end{array}$ & 81,12 & 85,55 \\
\hline C3 & $\begin{array}{l}\text { Tempat sampah yang tersedia di tempat saya melakukan } \\
\text { aktifitas terpisah antara sampah organik, anorganik, dan B3 }\end{array}$ & 54,59 & 68,79 \\
\hline C4 & $\begin{array}{l}\text { Saya selalu memisahkan sampah organik dan anorganik } \\
\text { dalam kehidupan sehari-hari }\end{array}$ & 52,55 & 65,90 \\
\hline C5 & $\begin{array}{l}\text { Sampah masker sekali pakai tidak dibuang ke tempat sampah } \\
\text { biasa }\end{array}$ & 49,49 & 64,74 \\
\hline
\end{tabular}




\begin{tabular}{|l|l|c|c|}
\hline \multirow{2}{*}{ Kode } & \multicolumn{1}{|c|}{ Pernyataan } & \multicolumn{2}{|c|}{$\begin{array}{c}\text { Perilaku peduli pengelolaan } \\
\text { sampah (\%) }\end{array}$} \\
\cline { 3 - 4 } & \multicolumn{1}{|c|}{$\begin{array}{c}\text { Sebelum } \\
\text { Sesudah }\end{array}$} \\
\hline C6 & $\begin{array}{l}\text { Saya pernah memanfaatkan sampah untuk kompos, souvenir, } \\
\text { atau barang lainnya }\end{array}$ & 76,02 & 81,50 \\
\hline C7 & $\begin{array}{l}\text { Sampah yang dihasilkan, tidak dikumpulkan dalam satu } \\
\text { wadah }\end{array}$ & 32,65 & 49,71 \\
\hline C8 & $\begin{array}{l}\text { Sampah yang dihasilkan tidak dibakar untuk mengurangi } \\
\text { sampah }\end{array}$ & 45,41 & 52,02 \\
\hline C9 & $\begin{array}{l}\text { Saling mengingatkan untuk memilah sampah agar sampah } \\
\text { dapat dimanfaatkan kembali }\end{array}$ & 89,29 & 97,69 \\
\hline C10 & $\begin{array}{l}\text { Mengurangi penggunaan barang sekali pakai dalam semua } \\
\text { aktifitas dengan membawa peralatan atau perlengkapan dari } \\
\text { rumah }\end{array}$ & 96,94 & 98,27 \\
\hline & Rata-rata & 67,06 & 76,00 \\
\hline
\end{tabular}

Perilaku peserta penyuluhan terhadap pengelolaan sampah (\%)

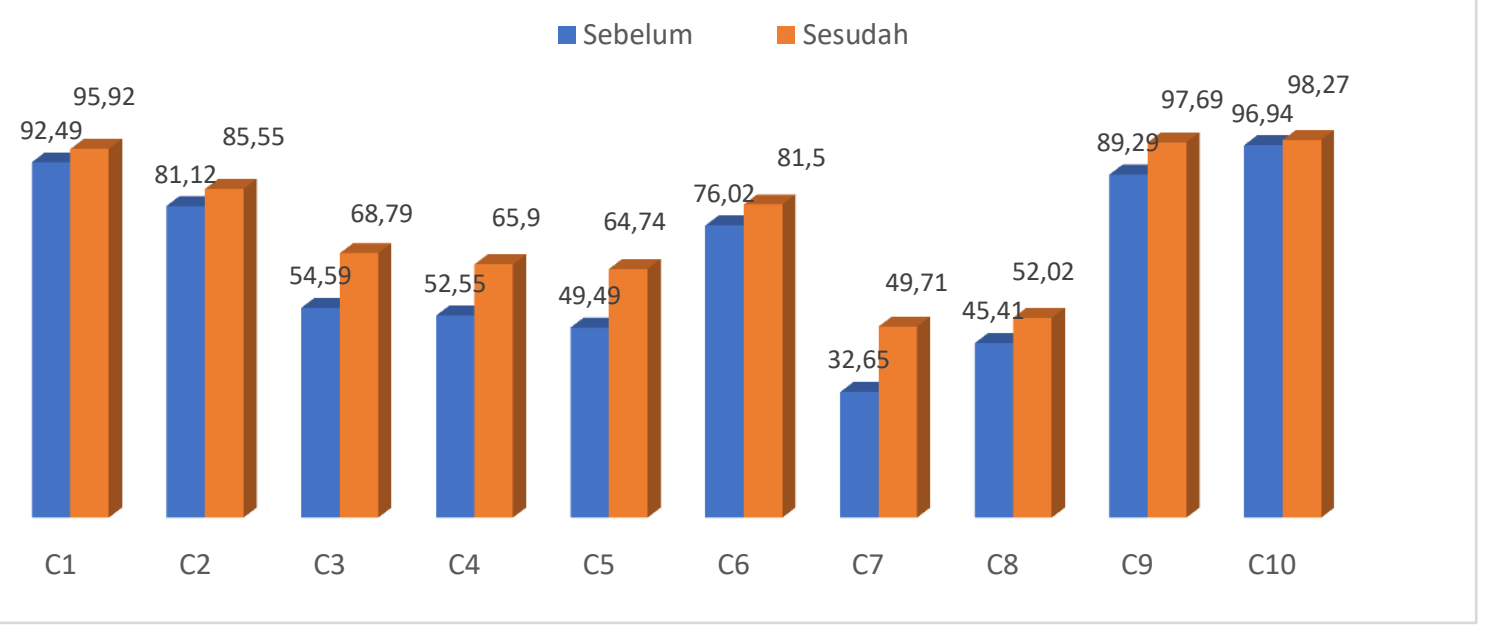

Gambar 8. Grafik perilaku peduli peserta penyuluhan terhadap pengelolaan sampah

Uji perubahan perilaku peduli pengelolaan sampah menggunakan uji t-berpasangan dengan taraf nyata 0,05 . Hipotesis pengujian $\mathrm{H} 0$ menyatakan tidak ada perbedaan perilaku peduli pengelolaan sampah sebelum dan sesudah penyuluhan, dan H1 menyatakan terdapat perbedaan perilaku peduli pengelolaan sampah sebelum dan sesudah penyuluhan. Hasil pengujian disajikan pada Tabel 6.

Tabel 7. Uji t-berpasangan perilaku peduli pengelolaan sampah

\begin{tabular}{|c|c|c|c|}
\hline \multicolumn{2}{|c|}{ Perilaku peduli (rata-rata) } & \multirow{2}{\text{Ujit-}}{$\begin{array}{c}\text { Kesimpulan } \\
\text { berpasangan } \\
\text { (Sig) }\end{array}$} & \\
\hline $\mathbf{6 7 , 0 6}$ & $\begin{array}{c}\text { Setelah } \\
\text { penyuluhan }\end{array}$ & 0,003 & Menolak H0 \\
\hline
\end{tabular}


Hasil uji menunjukkan nilai Sig $=0,003(\leq 5 \%)$ sehingga uji menolak H0 yang berarti terdapat perbedaan perilaku peduli pengelolaan sampah sebelum dan sesudah penyuluhan. Berdasarkan nilai rata-rata perilaku peduli menunjukkan bahwa nilai rata-rata perilaku peduli setelah penyuluhan mengalami peningkatan dibandingkan sebelum penyuluhan. Hal ini menunjukkan bahwa penyuluhan efektif telah meningkatkan kepedulian dalam perilaku peserta penyuluhan sebesar 8,94\%.

\section{Simpulan dan Rekomendasi}

Kegiatan PkM dengan judul Edukasi dan Aplikasi Pengelolaan Sampah Berbasis Pemilahan Sampah di FFUP menunjukkan efektif meningkatkan pemahaman tentang pengelolaan sampah hingga $4,58 \%$, meningkatkan sikap yang benar tentang pengelolaan sampah sebesar $0,94 \%$, dan meningkatkan perilaku peduli tentang pengelolaan sampah sebesar $8,94 \%$ Telah tersedia tempat sampah dengan pemilah antara sampah organik, anorganik, dan sampah medis (B3) di lingkungan FFUP dan poster yang memberi suasana edukasi setiap hari dan telah dibuat biopori yang dikelola tim kebersihan FFUP dalam rangka memaksimalkan pemanfaatan sampah organik berupa daun-daun kering. Serangkaian kegiatan ini memberi dampak positif bagi seluruh sivitas akademika FFUP baik dalam hal pengetahuan maupun penerapan.

Rekomendasi. Perlu dilakukan monitoring terhadap pemeliharaan dan optimalisasi biopori serta aplikasi pemilahan sampah di FFUP.

\section{Daftar Pustaka}

Anonim. (2008). Undang-Undang Republik Indonesia Nomor 18 Tahun 2008 Tentang Pengelolaan Sampah.

Anonim. (2020). Peraturan Pemerintah Republik Indonesia Nomor 27 Tahun 2020 Tentang Pengelolaan Sampah Spesifik.

Badan Pusat Statistik (BPS). (2017). Statistik Lingkungan Hidup Indonesia 2017, Badan Pusat Statistik Indonesia.

Diman S. (2017). Eco-Enzyme A Perfect House-Hold Organic Cleanser. International Journal of Engineering Technology, Management, and Applied Sciences. Volume 5, Issues 11, hal 19-23.

Eviati \& Sulaeman. (2009). Analisa Kimia Tanah, Tanaman, Air Dan Pupuk. Bogor : Badan Penelitian Dan Pengembangan Pertanian Departemen Pertanian.

Handayani DS, Budisulistiorini SH, dan Nuraini MR. (2009). Kajian Nilai Ekonomi Penerapan Konsep Daur Ulang Pada Tpa Jatibarang Kota Semarang. Jurnal PRESIPITASI Vol. 7 No.2 September 2009, ISSN 1907-187X.

Hardiana, DR. (2018). Implementasi Sustainable Development Goals (SDGs) dalam Pembangunan Kota Berkelanjutan di Jakarta.

Kamir, R. Brata dan Nelistya, Anne. 2008, Lubang Resapan Biopori. Jakarta. Penerbit Swadaya. 
Kumar N, Rajshree YA, Yadav A, Malhotra NH, Gupta N, dan Pushp P. (2019). Validation of eco-enzyme for improved water quality effect during large public gathering at river bank. International Journal of Human Capital in Urban Management (IJHCUM) Homepage: http://www.ijhcum.net/. Int. J. Hum. Capital Urban Manage., 4(3): 181-188, Summer 2019.

Megah SSI, Dewi DS, dan Wilany E. (2018). Pemanfaatan Limbah Rumah Tangga Digunakan Untuk Obat Dan Kebersihan. Minda Baharu, Volume 2, No .1 Juli 2018. Doi.10.33373/jmb.v2i1.2275 E-ISSN 2614-5944. Hal. 50-58

Samudro G, Samadikun BP, dan Sholehah FD. (2019). Edukasi Bank Sampah Dalam Rangka Meningkatkan Kinerja Sistem Pengelolaan Persampahan Kawasan Perumahan Permata Tembalang Kelurahan Kramas Kota Semarang. Jurnal Pasopati Vol. 1, No. 3 Tahun 2019

Saputra SNA, Mulasari SA. 2017. Pengetahuan, Sikap, dan Perilaku Pengelolaan Sampah pada Karyawan di Kampus. Jurnal Kesehatan Masyarakat. Vol. 11 No. 1. Maret 2017 pp 22-27, ISSN : 1978-0574

Suharjo, 2002. Kondisi pengelolaan sampah dan pengaruh terhadap Kesehatan masyarakat di DKI Jakarta. Media Penelitian dan Pengembangan Kesehatan. Volume 12 Nomor 4, Desember 2002. Badan Penelitian dan Pengembangan Kesehatan, Jakarta. pISSN 0852-9987, eISSN 2338-3445.

Sukib, Muti'ah, Siahaan, J., Supriadi. (2019). Meningkatkan Kesadaran Bahaya Sampah Laut Melalui Pendampingan pada Masyarakat Lokasi Wisata Pantai Kuranji.Jurnal Pengabdian Magister Pendidikan IPA (JPMPI). (2) 2. pp. 102-106

Walpole, RE. (1995). Pengantar Statistika. Edisi-3. PT. Gramedia, Jakarta.

Wijaya SA, Soebiyakto G, dan Ma'sumah M. Pembuatan Lubang Resapan Biopori Dan Pupuk Kompos Cair Dari Sampah Di Rw Ix, Kelurahan Kalirejo, Kecamatan Lawang, Kabupaten Malang. Jurnal Aplikasi Dan Inovasi Ipteks Soliditas. Volume 2 Nomor 2, Oktober Tahun 2019. ISSN Cetak : 2620-5076 ISSN Online : 2620-5068 